\title{
Enzymes of the glycogen cycle and glycolysis in various human neuromuscular disorders ${ }^{1}$
}

\author{
SALVATORE DI MAURO, CORRADO ANGELINI, AND CLAUDIA CATANI \\ From the Institute of General Pathology, G. Vernoni Research Unit for the Study of \\ Physiopathology, National Research Council, and the Neurological Clinic, \\ University of Padua, Italy
}

Previous investigations in several laboratories (Cooper and Miller, 1962; Schapira and Dreyfus, 1963; Pennington, 1964; Laudahn and Heyck, 1965) have shown that the activity of glycolytic enzymes is decreased, whereas that of mitochondrial enzymes is essentially unchanged in skeletal muscle from patients with progressive muscular dystrophy. It is still uncertain whether the above biochemical abnormalities reflect peculiarities in the metabolism of carbohydrates by the muscle fibres before the onset of degenerative changes, or whether they are merely the consequence of these changes.

Further, the activities of enzymes more directly concerned with glycogen metabolism have been little investigated in human dystrophic muscle. It is recorded only that the activity of phosphorylase is considerably decreased at advanced stages of the disease (Dreyfus, Schapira, and Schapira, 1954). Investigations of U.D.P.G.-glycogen synthetase activity in muscular dystrophy have not yet been reported, though this enzyme is believed to be an important regulatory factor in glycogen synthesis (Leloir, 1961).

In order to investigate aspects of carbohydrate metabolism in human dystrophic muscle for specific abnormalities, it was decided, therefore, to examine the relative tissue activities of phosphorylase, U.D.P.G.-glycogen synthetase, and of three sequential enzymes of the Embden-Meyerhof pathway, in muscles from patients with progressive muscular dystrophy and with neurogenic muscular wasting.

With the above objects in mind, it seemed proper to restrict our investigation to earlier enzymic changes which may precede the appearance of gross dystrophic manifestations and can, therefore, be more directly related to the primary pathological lesion.

\footnotetext{
${ }^{1}$ This work was supported by a grant from the Muscular Dystrophy Associations of America, Inc., to Professor Massimo Aloisi.

Substrates and cofactors for enzymic assays were purchased from Sigma Chemical Co., St. Louis, Mo., U.S.A. Crystalline enzymes from C. F. Boehringer \& Soehne, Mannheim, Germany. Other products were commercial grade reagents.
}

METHODS

Under local anaesthesia muscle was taken either from the palmaris longus or the vastus medialis in patients with progressive muscular dystrophy and with neurogenic muscular wasting. Additional muscle specimens, obtained either by biopsy from healthy subjects or in the course of routine orthopaedic operations, were used as controls.

A fragment of tissue was fixed in formalin-mercuric chloride fluid. Blocks were embedded in paraffin, cut at $8 \mu$, stained with haematoxylin-eosin, and used for light microscopy. The unfixed remainder was freed from any obvious connective tissue, rapidly frozen, and stored at $-25^{\circ} \mathrm{C}$. until assay.

At the time of analysis thawed and blotted aliquots of about $200 \mathrm{mg}$. were weighed out in an analytical balance. Homogenates (final concentration, $10 \%$ ) were prepared from the tissue with a Potter-Elvehjem appa-

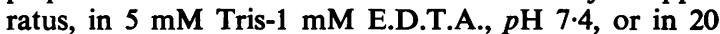
mM K-phosphate buffer, $p H$ 8.0. Tris-E.D.T.A. homogenates were used for assay of U.D.P.G.-glycogen synthetase (U.D.P. glucose: glycogen $\alpha$-4-glucosyltransferase, E.C. 2.4.1.11) and phosphorylase (phosphorylase phosphohydrolase, E.C. 3.1.3.17). For the latter purpose homogenates were further diluted with three volumes of $20 \mathrm{mM} \mathrm{NaF}, 1 \mathrm{mM}$ E.D.T.A., $p \mathrm{H}$ $6 \cdot 0$. The 10,000 g. $\times 10 \mathrm{~min}$. supernatant fraction of $10 \%$ homogenates in phosphate buffer was used for the assay of the glycolytic enzymes.

The U.D.P.G.-glycogen synthetase was measured in the presence of $10 \mathrm{mM}$ glucose-6-phosphate, in a reaction mixture having the same composition as the standard medium of Leloir and Goldemberg (1960), except that it was buffered with Tris-acetate, $p \mathbf{H ~ 7 . 5 ~ ( G a l l u c c i , ~}$ Novello, Margreth, and Aloisi, 1966).

Phosphorylase activity was measured in the presence of $1 \mathrm{mM}$ AMP at $p \mathrm{H} 6.0$, according to the procedure of Cori, Illingworth, and Keller (1955). $P_{i}$ was determined on appropriate aliquots of the reaction mixture by the method of Lindberg and Ernster (1966).

Phosphofructokinase (A.T.P.: D-fructose-6-phosphate 1-phosphotransferase, E.C. 2.7.1.11) activity was determined spectrophotometrically by the method of Ling, Byrne, and Lardy (1955), in a reaction medium of the following composition: $33.3 \mathrm{mM}$ Tris, $p H 8.0 ; 6.0 \mathrm{mM}$ 
$\mathrm{MgCl}_{2} ; 2.0 \mathrm{mM}$ A.T.P.; 0.1 mM NADH; $1.0 \mathrm{mM}$ fructose-6-phosphate, and an excess of crystalline aldolase, triose-phosphate isomerase, and $\alpha$-glycerophosphate dehydrogenase.

Aldolase (fructose-1, 6-diphosphate: D-glyceraldehyde3-phosphatelyase, E.C. 4.1.2.13) activity was determined

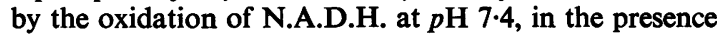
of fructose-1, 6-diphosphate, triose-phosphate isomerase, and $\alpha$-glycerophosphate dehydrogenase (Wu and Racker, 1959); lactate dehydrogenase (D-lactate: N.A.D. oxidoreductase, E.C. 1.1.1.28) by the oxidation of N.A.D.H. by pyruvate at $p \mathrm{H} \mathrm{7.4}$ (Kornberg, 1955).

Serum aldolase activity was measured by the colorimetric method of Sibley and Lehninger (1949a), expressed as $\mu$ litres of fructose-1, 6-diphosphate split per hour by $1 \mathrm{ml}$. of serum at $38^{\circ} \mathrm{C}$. The normal ranges are 3-10 units (Sibley and Lehninger, 1949b).

Protein measurements in T.C.A. precipitates of whole tissue homogenates and tissue extracts were made by the Lowry, Rosebrough, Farr, and Randall (1951) procedure.

\section{CLINICAL MATERIAL AND HISTOLOGICAL CLASSIFICATION}

Muscle specimens were made available to us from 41 patients: 21 were cases of progressive muscular dystrophy (Table I) and 20 were cases of neurogenic muscular wasting (Table II).

All cases of progressive muscular dystrophy were classified according to the criteria of Walton and Nattrass (1954). Serum aldolase activities were measured in most cases. In agreement with earlier data in the literature (Thomson, 1962; Heyck and Laudahn, 1965), these

\section{TABLE I}

\section{PROGRESSIVE MUSCULAR DYSTROPHY}

\begin{tabular}{|c|c|c|c|c|c|}
\hline $\begin{array}{l}\text { Case } \\
\text { No. }\end{array}$ & $\begin{array}{l}\text { Type of Muscular } \\
\text { Dystrophy }\end{array}$ & $\begin{array}{l}\text { Age } \\
\text { (yr.) }\end{array}$ & Sex & $\begin{array}{l}\text { Histological } \\
\text { Group }\end{array}$ & $\begin{array}{l}\text { Serum } \\
\text { Aldolase } \\
\text { (units per ml.) }\end{array}$ \\
\hline 1 & Duchenne & 4 & $\mathbf{M}$ & 1 & - \\
\hline 2 & Duchenne & 8 & $\mathbf{M}$ & 1 & 32 \\
\hline $3^{1}$ & Duchenne & 3 & $\mathbf{M}$ & 1 & - \\
\hline $4^{1}$ & Duchenne & 6 & $\mathbf{M}$ & 1 & 74 \\
\hline 5 & Duchenne & 16 & $\mathbf{M}$ & 1 & 24 \\
\hline 6 & Duchenne & 5 & $\mathbf{M}$ & 2 & 170 \\
\hline 7 & Duchenne & 4 & $\mathbf{M}$ & 2 & - \\
\hline 8 & Duchenne & 6 & $\mathbf{M}$ & 2 & 118 \\
\hline $9^{2}$ & Duchenne & 4 & $\mathbf{M}$ & 2 & 91 \\
\hline $10^{2}$ & Duchenne & 7 & $\mathbf{M}$ & 2 & 50 \\
\hline 11 & Duchenne & 6 & $\mathbf{M}$ & 2 & - \\
\hline 12 & Duchenne & 6 & $\mathbf{M}$ & 2 & 140 \\
\hline 13 & Limb-girdle & 36 & $\mathbf{M}$ & 1 & 38 \\
\hline 14 & Limb-girdle & 42 & $\mathbf{M}$ & 2 & - \\
\hline 15 & Limb-girdle & 18 & $\mathbf{M}$ & 2 & 25 \\
\hline 16 & $\begin{array}{l}\text { Facio-scapulo- } \\
\text { humeral }\end{array}$ & 14 & $\mathbf{F}$ & 1 & 29 \\
\hline 17 & $\begin{array}{l}\text { Facio-scapulo- } \\
\text { humeral }\end{array}$ & 49 & $\mathbf{F}$ & 1 & 9 \\
\hline 18 & $\begin{array}{l}\text { Facio-scapulo- } \\
\text { humeral }\end{array}$ & 11 & $\mathbf{F}$ & 2 & 29 \\
\hline 19 & $\begin{array}{l}\text { Dystrophia } \\
\text { myotonica }\end{array}$ & 38 & $\mathbf{F}$ & 1 & - \\
\hline $20^{3}$ & $\begin{array}{l}\text { Dystrophia } \\
\text { myotonica }\end{array}$ & 34 & $\mathbf{F}$ & 1 & 25 \\
\hline $21^{3}$ & $\begin{array}{l}\text { Dystrophia } \\
\text { myotonica }\end{array}$ & 29 & $\mathbf{F}$ & 1 & 21 \\
\hline $1,2,3$ & Siblings & & & & \\
\hline
\end{tabular}

TABLE II

NEUROGENIC MUSCULAR DISEASE

\begin{tabular}{|c|c|c|c|c|}
\hline $\begin{array}{l}\text { Case } \\
\text { No. }\end{array}$ & Condition & Age & Sex & $\begin{array}{l}\text { Histological } \\
\text { Group }\end{array}$ \\
\hline 1 & Chronic peripheral neuritis & $45 \mathrm{yr}$. & $\mathbf{M}$ & 1 \\
\hline 2 & Chronic peripheral neuritis & 35 yr. & $\mathbf{F}$ & 1 \\
\hline 3 & Chronic peripheral neuritis & $39 \mathrm{yr}$. & $\mathbf{F}$ & 1 \\
\hline 4 & Chronic peripheral neuritis & $52 \mathrm{yr}$. & $\mathbf{M}$ & 1 \\
\hline 5 & Chronic polyneuritis & $28 \mathrm{yr}$. & $\mathbf{F}$ & 1 \\
\hline 6 & Chronic polyneuritis & $50 \mathrm{yr}$. & $\mathbf{F}$ & 1 \\
\hline 7 & Chronic polyneuritis & $18 \mathrm{yr}$. & $\mathbf{F}$ & 2 \\
\hline 8 & $\begin{array}{l}\text { Acute polyneuritis } \\
\text { (Guillain-Barré) }\end{array}$ & $43 \mathrm{yr}$. & $\mathbf{F}$ & $\mathbf{1}$ \\
\hline 9 & Acute polyneuritis & $62 \mathrm{yr}$. & $\mathbf{F}$ & 1 \\
\hline 10 & Amyotrophic lateral sclerosis & $54 \mathrm{yr}$. & $\mathbf{F}$ & 1 \\
\hline 11 & Amyotrophic lateral sclerosis & 58 yr. & $\mathbf{F}$ & 1 \\
\hline 12 & Amyotrophic lateral sclerosis & 70 yr. & $\mathbf{F}$ & 1 \\
\hline 13 & Amyotrophic lateral sclerosis & $66 \mathrm{yr}$. & $\mathbf{F}$ & 1 \\
\hline 14 & Amyotrophic lateral sclerosis & 43 yr. & $\mathbf{F}$ & 2 \\
\hline 15 & Werdnig-Hoffmann disease & 7 mth. & $\mathbf{F}$ & 2 \\
\hline 16 & Werdnig-Hoffmann disease & $18 \mathrm{mth}$. & $\mathbf{F}$ & 2 \\
\hline 17 & Werdnig-Hoffmann disease & 6 yr. & $\mathbf{M}$ & 2 \\
\hline 18 & Werdnig-Hoffmann disease & $8 \mathrm{mth}$. & $\mathbf{M}$ & $\overline{2}$ \\
\hline 19 & Werdnig-Hoffmann disease & 3 mth. & $\mathbf{F}$ & 2 \\
\hline 20 & Werdnig-Hoffmann disease & 2 yr. & $\mathbf{M}$ & 2 \\
\hline
\end{tabular}

were found most elevated in the Duchenne type of dystrophy, and less so in the limb-girdle type and in dystrophia myotonica. Patients with the Duchenne type of dystrophy were at an early stage of the disease: all patients were ambulant, although they showed a more or less marked rolling gait and muscular weakness.

In order to make possible a comparison between enzymic activities in progressive muscular dystrophy and neurogenic muscular wasting at similar stages of each process, and also at different stages of the same disease, affected muscles were grouped on the basis of histological criteria, irrespective of the specific ciinical disease. Histological classification was based on the type and extension of elementary changes in the muscle fibres, such as simple atrophy, hypertrophy, increase in the number and centralization of sarcolemmal nuclei, degenerative changes, and increase of interstitial fat and connective tissue. These elementary changes are present in both progressive muscular dystrophy and neurogenic muscular diseases, the variable proportion of atrophic and degenerative features depending essentially on the rate of progression of the disease (Aloisi, 1965).

Two stages, corresponding to the very early and to the more advanced manifestations of the pathological process were identified. Group 1 included cases showing histological appearances characterized by simple atrophy, hypertrophy, increase in number and centralization of sarcolemmal nuclei. Degenerative changes, when present, were early and involved either a large number of fibres, as in some cases of progressive muscular dystrophy, or, as was more frequently observed with neurogenic muscular wasting, were limited to a few scattered fibres. There was little evidence of adipose or connective tissue infiltration. On the other hand, the cases included in group 2 showed marked atrophy, greatly increased numbers of subsarcolemmal nuclei, advanced and/or widespread degenerative changes, and appreciable connective tissue infiltration. 
TABLE III

ACTIVITIES OF PHOSPHOFRUCTOKINASE, ALDOLASE, AND LACTATE DEHYDROGENASE IN NORMAL AND DYSTROPHIC HUMAN MUSCLE ${ }^{1}$

\begin{tabular}{|c|c|c|c|c|c|c|c|}
\hline Muscle & $\begin{array}{l}\text { Histological } \\
\text { Group }\end{array}$ & $\begin{array}{l}\text { Phosphofructokinase } \\
\text { ( } \mu \text { Moles F.D.P. } \\
\text { formed /mg.pr./min.) }\end{array}$ & $\begin{array}{l}\text { Percentage } \\
\text { of Normal }\end{array}$ & $\begin{array}{l}\text { Aldolase ( } \mu \text { Moles } \\
\text { N.A.D.H. ox/mg. } \\
\text { pr./min.) }\end{array}$ & $\begin{array}{l}\text { Percentage } \\
\text { of Normal }\end{array}$ & $\begin{array}{l}\text { Lactate Dehydro- } \\
\text { genase ( } \mu \text { Moles } \\
\text { N.A.D.H. ox/mg. } \\
\text { pr./min.) }\end{array}$ & $\begin{array}{l}\text { Percentage } \\
\text { of Normal }\end{array}$ \\
\hline Control & - & $\begin{array}{c}0.370 \pm 0.030 \\
(11)\end{array}$ & - & $\begin{array}{c}0.840 \pm 0.051 \\
(11)\end{array}$ & - & $\begin{array}{c}2 \cdot 25 \pm 0 \cdot 28 \\
(10)\end{array}$ & - \\
\hline $\begin{array}{l}\text { Neurogenic muscular } \\
\text { wasting }\end{array}$ & 1 & $0.307 \underset{(9)}{ \pm} 0.011$ & 83 & $0.706 \underset{(9)}{ \pm} 0.024$ & 84 & $1.60 \underset{(6)}{ \pm} 0.19$ & 71 \\
\hline $\begin{array}{l}\text { Progressive muscular } \\
\text { dystrophy }\end{array}$ & 1 & $\begin{array}{c}0.273 \pm 0.034 \\
(11)\end{array}$ & 74 & $\begin{array}{c}0.709 \pm 0.078 \\
(11)\end{array}$ & 84 & $\begin{array}{c}1.89 \pm 0.18 \\
(11)\end{array}$ & 84 \\
\hline $\begin{array}{l}\text { Neurogenic muscular } \\
\text { wasting }\end{array}$ & 2 & $0.217 \underset{(4)}{ \pm} 0.067$ & 58 & $0.350 \underset{(4)}{ \pm} 0.095$ & 42 & $0.69 \pm 0.14$ & 31 \\
\hline $\begin{array}{l}\text { Progressive muscular } \\
\text { dystrophy }\end{array}$ & 2 & $\begin{array}{c}0.177 \pm 0.026 \\
(10)\end{array}$ & 48 & $0.430 \underset{(9)}{ \pm} 0.072$ & 51 & $1 \cdot 17 \underset{(8)}{ \pm} 0.16$ & 52 \\
\hline
\end{tabular}

${ }^{1}$ Values are given \pm S.E.M. and number of analysis in parentheses.

TABLE IV

ACTIVITIES OF GLYCOGEN SYNTHETASE AND PHOSPHORYLASE IN NORMAL AND DYSTROPHIC HUMAN MUSCLE ${ }^{1}$

\begin{tabular}{|c|c|c|c|c|c|}
\hline Muscle & $\begin{array}{l}\text { Histological } \\
\text { Group }\end{array}$ & $\begin{array}{l}\text { Glycogen Synthetase } \\
\text { ( } \mu \text { Moles U.D.P. formed/mg.pr./hr.) }\end{array}$ & $\begin{array}{l}\text { Percentage } \\
\text { of Normal }\end{array}$ & $\begin{array}{l}\text { Phosphorylase } \\
\text { ( } \mu \text { Moles Pi formed/mg.pr/10min.) }\end{array}$ & $\begin{array}{l}\text { Percentage } \\
\text { of Normal }\end{array}$ \\
\hline Control & - & $\begin{array}{c}2 \cdot 30 \pm 0.21 \\
(10)\end{array}$ & - & $\begin{array}{c}7 \cdot 40 \pm 0 \cdot 37 \\
(10)\end{array}$ & - \\
\hline $\begin{array}{l}\text { Neurogenic muscular } \\
\text { wasting }\end{array}$ & 1 & $\begin{array}{c}2 \cdot 28 \pm 0.24 \\
(9)\end{array}$ & 99 & $\begin{array}{c}6.31 \pm 0.66 \\
(9)\end{array}$ & 85 \\
\hline $\begin{array}{l}\text { Progressive muscular } \\
\text { dystrophy }\end{array}$ & 1 & $\begin{array}{c}2 \cdot 30 \pm 0 \cdot 15 \\
(10)\end{array}$ & 100 & $\begin{array}{c}3 \cdot 65 \pm 0 \cdot 39 \\
(10)\end{array}$ & 49 \\
\hline $\begin{array}{l}\text { Neurogenic muscular } \\
\text { wasting }\end{array}$ & 2 & $\begin{array}{c}1.95 \pm 0.39 \\
(6)\end{array}$ & 85 & $\begin{array}{c}3.33 \pm 0.95 \\
(5)\end{array}$ & 45 \\
\hline $\begin{array}{l}\text { Progressive muscular } \\
\text { dystrophy }\end{array}$ & 2 & $1 \cdot 43 \underset{(7)}{ \pm} 0 \cdot 13$ & 62 & $1.86 \pm 0.25$ & 25 \\
\hline
\end{tabular}

${ }^{1}$ Values are given \pm S.E.M. and number of analysis in parentheses.

\section{RESULTS}

The data in Table III show that in progressive muscular dystrophy there is a considerable decrease in the activity of the three glycolytic enzymes studied, namely, phosphofructokinase, aldolase, and lactate dehydrogenase, but no greater than that found in neurogenic muscular wasting at comparable early histological stages of the process. It may also be noted from Table III that the decrease in activity was of the same order for each of the glycolytic enzymes, so that their reportedly constant ratios in several mammalian skeletal muscles (Pette and Bücher, 1963) were largely unaffected in the course of both progressive muscular dystrophy and neurogenic muscular diseases.

Likewise, the changes in U.D.P.G.-glycogen synthetase activity (Table IV) were independent of the type of muscular disease, although they occurred later than those of glycolytic enzymes. A definite decrease of U.D.P.G.-glycogen synthetase became apparent only during the late stages of the disease.

In contrast, however, Table IV shows particular differences in phosphorylase activity in progressive muscular dystrophy as compared with neurogenic muscular diseases. In progressive muscular dystrophy a marked decrease of phosphorylase activity is apparent in the early stages of the disease and progresses further with time. The relationship of the changes in muscle phosphorylase activity with the clinical progress of progressive muscular dystrophy is also supported by the comparative data on affected siblings at various stages of the disease (Table V). In neurogenic muscular wasting, however, muscle phosphorylase activity diminishes significantly only in the late stages, and even then it remains about twice as high as in progressive muscular dystrophy.

\section{DISCUSSION}

The decreased activity of glycolytic enzymes in human dystrophic muscle has received considerable attention in recent years, particularly since their excessive leakage into the bloodstream here, but not in neurogenic wasting, provides important diagnostic evidence for the presence of the disease (see, for discussion, Pennington, 1964). However, the data presented here show that, despite these substantial differences between the serum activities of glycolytic enzymes in progressive muscular 
TABLE V

ACTIVITY OF MUSCLE PHOSPHORYLASE IN SIBLINGS AFFECTED WITH DUCHENNE PROGRESSIVE MUSCULAR DYSTROPHY

\begin{tabular}{|c|c|c|c|c|}
\hline $\begin{array}{l}\text { Case Nc } \\
(\text { see } \\
\text { Table I) }\end{array}$ & $\begin{array}{l}\text { Age } \\
(y r .)\end{array}$ & $\begin{array}{l}\text { Phosphorylase activity } \\
\text { ( } \mu \text { Moles Pi/10 min./mg. } \\
\text { protein) }\end{array}$ & $\begin{array}{l}\text { Percentage } \\
\text { of Normal }\end{array}$ & $\begin{array}{l}\text { Histological } \\
\text { Group }\end{array}$ \\
\hline 3 & 3 & $5 \cdot 35$ & 72 & 1 \\
\hline 4 & 6 & $3 \cdot 13$ & 42 & 1 \\
\hline 9 & 4 & 2.65 & 36 & 2 \\
\hline 10 & 7 & 1.68 & 23 & 2 \\
\hline
\end{tabular}

dystrophy and in neurogenic muscular disorders (Thomson, 1962; Heyck and Laudahn, 1965), the decrease of their activities in muscle is of the same order of magnitude in both conditions at comparable gross histological stages, i.e., it is apparently secondary to the muscular wasting itself.

Because of the similarities in the behaviour of glycolytic enzymes and also U.D.P.G.-glycogen synthetase in both progressive muscular dystrophy and in neurogenic muscular wasting, our finding that muscle phosphorylase activity decreases earlier and more markedly in progressive muscular dystrophy is of considerable interest as a possibly specific biochemical feature of the dystrophic process.

While the above data support reports that the utilization of glucose is less affected than that of glycogen, at least in animal hereditary muscular dystrophy (Fink, 1961; Dale, 1965), the actual mechanism(s) diminishing glycogenolysis more in progressive muscular dystrophy than in neurogenic muscular wasting are still obscure.

Two alternative explanations may be entertained. One is that progressive muscular dystrophy, unlike neurogenic muscular disorders, involves a selective loss of a special type of muscle fibre with high phosphorylase activity. The other is that dystrophic muscle reverts to a less differentiated, embryonic type with low phosphorylase activity.

The first hypothesis rests on the fact that adult human muscle, like that of other vertebrates, contains fibres with different enzymic contents (Dubowitz and Pearse, 1961). Though their proportions are variable, two main types of fibres are generally described, which differ widely in their content of phosphorylase as well as of a number of glycolytic and oxidative enzymes (for review, see Beckett, 1962). In the present context, it is of interest that phosphorylase-rich fibres, which are more numerous in 'white' muscles, appear to be particularly affected in dystrophic muscles of the domestic fowl (Cosmos, 1966). This first hypothesis, moreover, does not conflict with our findings that
U.D.P.G.-glycogen synthetase, unlike phosphorylase, is affected to the same degree in both progressive muscular dystrophy and in neurogenic muscular diseases. Measurements carried out in this laboratory on homogenates of different muscles from several species have so far shown that total U.D.P.G.glycogen synthetase is quite uniformly distributed in 'white' and 'red' muscles (Margreth et al., unpublished data). Thus a loss of U.D.P.G.-glycogen synthetase activity would depend more on the number than on the type of fibres involved.

The second hypothesis accords with the histochemical and biochemical evidence that phosphorylase activity is low in immature fibres both from embryonic avian muscle (Cosmos, 1966) and from regenerating rat muscle (Gallucci et al., 1966), and increases with differentiation. However, both mechanisms may in fact be involved in progressive muscular dystrophy since the degeneration of phosyphorylase-rich 'white' fibres may be combined with dedifferentiation changes toward less mature 'red' fibres (see, for discussion, Muscatello, Margreth, and Aloisi, 1965).

The above considerations relate to the early or stages of the dystrophic process, since our datao show that, despite considerable enzymic differencesi between progressive muscular dystrophy and neurogenic muscular wasting, the latter may also eventually, exhibit a marked decrease of phosphorylase a advanced stages of the disease.

The metabolic and functional similarities between dystrophic and embryonic muscle has suggested to several authors (Dreyfus, Demos, Schapira, and Schapira 1962; Brust, 1966) the possibility that the normal differentiation of skeletal muscle might be impaired in progressive muscular dystrophy.

Although the failure in dystrophy to maintain a normal content of muscle phosphorylase would be consistent with the above hypothesis, it is at present difficult to assign to impaired phosphorylase activity a prominent role in the onset of the degenerative changes of the muscle fibres. Absence of muscle phosphorylase, as in McArdle's disease (McArdle, 1951), is not regularly accompanied by gross dystrophic manifestations, although these were reported in some cases (Rowland, Fahn, and Schotland, 1963). It cannot be excluded that changes of phosphorylase activity in dystrophic muscle may be secondary to more specific enzymic alterations (Hooton and Watts, 1966).

A decrease in muscle phosphorylase activity thus appears to be a biochemical characteristic of muscular dystrophy, which may even prove of additional diagnostic use in differentiating early muscular dystrophy from neurogenic muscular disease. 
SUMMARY

The activities in skeletal muscle of phosphofructokinase, aldolase, lactate dehydrogenase, U.D.P.G.glycogen synthetase and phosphorylase, have been compared in progressive muscular dystrophy and in neurogenic muscular wasting.

Both myogenic and neurogenic cases have been classified in two main groups, according to the severity and/or extent of histological changes, in order to make possible a comparison of the enzyme pattern in early and advanced stages of each type of disease.

A comparable decrease in the activities of the three glycolytic enzymes and of U.D.P.G.-glycogen synthetase was found in both progressive muscular dystrophy and neurogenic muscular wasting and according to the stage of the disease.

In contrast phosphorylase showed a loss of activity which was earlier and far more marked in progressive muscular dystrophy than in neurogenic diseases. The possible role of this unusual behaviour of phosphorylase in the pathogenesis of progressive muscular dystrophy is discussed.

We wish to express our deepest gratitude to Professor Massimo Aloisi for working facilities, support, and helpful advice in examining and classifying the histological material. Our warm thanks are due to Professor Giambattista Belloni for encouragement in the course of the work. We are indebted to Dr. A. Margreth at the Institute of General Pathology for helpful suggestions and criticism. Dr. W. H. S. Thomson, Research Laboratory, Knightswood Hospital, Glasgow, very kindly revised the manuscript before its submission for publication. The technical help of Mr. Renato Siligardi is gratefully acknowledged.

\section{REFERENCES}

Aloisi, M. (1965). Critical observations on morphological and biochemical aspects of human myopathies. In Myopathien, edited by R. Beckmann, pp. 104-108. Thieme, Stuttgart.

Beckett, E. B. (1962). Some applications of histochemistry to the study of skeletal muscle. Rev. canad. Biol., 21, 391-407.

Brust, M. (1966). Relative resistance to dystrophy of slow skeletal muscle of the mouse. Amer. J. Physiol., 210, 445-451.

Cooper, A. C., and Miller, J. R. (1962). Progressive muscular dystrophy: a review. Rev. canad. Biol., 21, 337-351.

Cori, G. T., Illingworth, B., and Keller, P. J. (1955). Muscle phosphorylase. In Methods in Enzymology, edited by S. P. Colowick, and N. O. Kaplan, Vol. 1, pp. 200-205. Academic Press, New York.

Cosmos, E. (1966). Enzymatic activity of differentiating muscle fibres. I. Development of phosphorylase in muscles of the domestic fowl. Develop. Biol., 13, 163-181.

Dale, R. A. (1965). Correlations between components of the glycolytic pathway. Biochem. J., 96, 347-353.
Dreyfus, J. C., Demos, J., Schapira, F., and Schapira, G. (1962). La lacticodéshydrogénase musculaire chez le myopathe: persistance apparente du type foetal. C. R. Acad. Sci., 254, 4384-4386.

—. Schapira, G., and Schapira, F. (1954). Biochemical study of muscle in progressive muscular dystrophy. J. clin. Invest., 33, 794-797.

Dubowitz, V., and Pearse, A. G. E. (1961). Enzymic activity of normal and dystrophic human muscle: a histochemical study. J. Path. Bact., 81, 365-378.

Fink, K. (1961). Biochemical studies of skeletal muscle in mice with hereditary muscular dystrophy. Fed. Proc., 20, Part I. Abstracts, p. 303.

Gallucci, V., Novello, F., Margreth, A., and Aloisi, M. (1966). Biochemical correlates of discontinuous muscle regeneration in the rat. Brit. J. exp. Path., 47, 215-227.

Heyck, H., and Laudahn, G. (1965). Fermentchemische Serumbefunde bei Myopathien. In Myopathien, edited by R. Beckmann, pp. 176-187. Thieme, Stuttgart.

Hooton, B. T., and Watts, D. C. (1966). Adenosine 5'-triphosphatecreatine phosphotransferase from dystrophic mouse skeletal muscle. Biochem. J., 100, 637-646.

Kornberg, A. (1955). Lactic dehydrogenase of muscle. In Methods in Enzymology, edited by S. P. Colowick, and N. O. Kaplan, Vol. I, pp. 441-443. Academic Press, New York.

Laudahn, G., and Heyck, H. (1965). Muskelenzym-Befunde bei progressiver Muskeldystrophie. In Myopathien, edited by R. Beckmann, pp. 165-175. Thieme, Stuttgart.

Leloir, L. F. (1961). The biosynthesis of glycogen, starch, and other polysaccharides. In The Harvey Lectures 1960-1961, Series 56, pp. 23-43. Academic Press, New York and London.

- , and Goldemberg, S. H. (1960). Synthesis of glycogen from uridine diphosphate glucose in liver. J. biol. Chem., 235, 919-923.

Lindberg, O., and Ernster, L. (1956). Determination of organic phosphorus compounds by phosphate analysis. In Methods of Biochemical Analysis, edited by D. Glick, pp. 1-22. Interscience, New York.

Ling, K. H., Byrne, W. L., and Lardy, H. (1955). Phosphohexokinase. In Methods in Enzymology, edited by S. P. Colowick, and N. O. Kaplan, Vol. 1, pp. 306-310. Academic Press, New York.

Lowry, O. H., Rosebrough, N. J., Farr, A. L., and Randall, R. J. (1951). Protein measurement with the folin phenol reagent. J. biol. Chem., 193, 265-275.

McArdle, B. (1951). Myopathy due to a defect in muscle glycogen breakdown. Clin. Sci., 10, 13-35.

Muscatello, U., Margreth, A., and Aloisi, M. (1965). On the differential response of sarcoplasm and myoplasm to denervation in frog muscle. J. Cell Biol., 27, 1-24.

Pennington, R. J. (1964). Biochemical aspects of muscle disease. In Disorders of Voluntary Muscle, edited by J. N. Walton, pp. 255-274. Churchill, London.

Pette, D., and Bücher, T. (1963). Proportionskonstante Gruppen in Beziehung zur Differenzierung der Enzymaktivitätsmuster von Skelett-Muskeln des Kaninchens. Hoppe-Seylers Z. physiol Chem., 331, 180-195.

Rowland, L. P., Fahn, S., and Schotland, D. L. (1963). McArdle's disease. Arch. Neurol. (Chic.), 9, 325-342.

Schapira, G., and Dreyfus, J. C. (1963). Biochemistry of progressive muscular dystrophy. In Muscular Dystrophy in Man and Animals, edited by G. H. Bourne and M. N. Golarz, pp. 48-87. Karger, Basel and New York.

Sibley, J. A., and Lehninger, A. L. (1949a). Determination of aldolase in animal tissues. J. biol. Chem., 177, 859-872.

- $-1949 \mathrm{~b})$. Aldolase in the serum and tissues of tumorbearing animals. J. nat. Cancer Inst., 9, 303-309.

Thomson, W. H. S. (1962). Sources of error in the biochemical diagnosis of muscular dystrophy. J. Neurol. Neurosurg. Psychiat., 25, 191-202.

Walton, J. N., and Nattrass, F. J. (1954). On the classification, natural history and treatment of the myopathies. Brain, 77, 169-231.

Wu, R., and Racker, E. (1959). Regulatory mechanisms in carbohydrate metabolism. III. Limiting factors in glycolysis of ascites tumor cells. J. biol. Chem., 234, 1029-1035. 